\title{
HUBUNGAN DUKUNGAN SOSIAL KELUARGA TERHADAP PELAKSANAAN PERSONAL HYGIENE LANSIA DI PANTI BINA LANJUT USIA JAYAPURA
}

\author{
Risman Hidayat Takamokan ${ }^{1}$, Viertianingsih Patungo ${ }^{1}$, Kismiyati $^{2}$ \\ ${ }^{1}$ Prodi Keperawatan Stikes Jayapura, ${ }^{2}$ Politeknik Kesehatan Jayapura \\ Email: prodikep.stikesjypr@yahoo.com
}

\begin{abstract}
ABSTRAK
Personal hygiene merupakan hal yang sangat penting dan harus dipertahankan karena personal hygiene akan mempengaruhi kesehatan, kenyamanan, keamanan dan kesejahteraan. Lansia sangat rentan dengan berbagai penyakit dan mengalami penurunan fisik, sehingga kebutuhan personal hygiene lansia pun semakin tinggi. Dukungan keluarga sangat diharapkan dapat membantu pemenuhan personal hygiene lansia. Tujuan penelitian untuk mengetahui hubungan dukungan sosial keluarga terhadap pelaksanaan personal hygiene lansia di Panti Bina Lanjut Usia Kabupaten Jayapura.Jenis penelitian yaitu penelitian deskriptif analitik dengan rancangan cross sectional study. Lokasi penelitian dilakukan di Panti Bina Lanjut Usia Kabupaten Jayapura pada bulan Juli 2016. Populasi dalam penelitian adalah seluruh lansia di Panti Bina Lanjut Usia Kabupaten Jayapura dengan jumlah sampel sebanyak 43 lansia. Data diperoleh menggunakan kuesioner dan dianalisa dengan uji chi square. Hasil penelitian menunjukkan ada hubungan dukungan sosial keluarga terhadap pelaksanaan personal hygiene lansia di Panti Bina Lanjut Usia Kabupaten Jayapura. Hasil penelitian diperoleh bahwa dukungan sosial keluarga lansia dalam pemenuhan personal hygiene lansia di Panti Bina Lanjut Usia sebagian besar kurang baik $(53,5 \%)$ dan pelaksanaan personal hygiene lansia di Panti Bina Lanjut Usia sebagian besar dilakukan dengan baik (69,8\%). Dengan tingginya dukungan sosial keluarga terhadap pemenuhan personal hygiene lansia, sehingga lansia dapat memenuhi kebutuhan personal hygiene.
\end{abstract}

Kata kunci $\quad$ : Dukungan Sosial Keluarga, Personal Hygiene, Lansia 


\begin{abstract}
Personal hygiene is very important and must be maintained for personalhygiene will affects health, convenience, security and welfare. The elderly are vulnerable with various diseases and physicaldecline,therefore thepersonal hygieneneeds of the elderlyexcelsior. Highly expected that family support gets to help personal hygiene accomplishment of the elderly. The aim of the research is to determine the corelation between social family support and implementation of personal hygieneof the elderly at social residential for elderly in jayapura regency. This research is descriptive analytic research with cross sectional study design. The research location is in Social Residential for Elderly in Jayapura Regency in July 2016. Population were the elderly at social residential in jayapura regency with total sample are 43 elders. the data were obtained using a questioner and analysed by chi square test. the results showed there is corelation between social family support and personal hygieneof elderly at social residential for elderly in jayapura regency. The result showed that social family support in the fulfillment of personal hygiene of the elderly in social residentialfor elderly mostly in less category $(53,5 \%)$, and the implementation of personal hygieneof the elderly largely performed well $(69,8 \%)$. The high social family support to accomplish personal hygiene of elderly, so they can be fulfilled their need in personal hygiene.
\end{abstract}

Keyword: Social Family Support, Personal Hygiene, Elderly 


\section{PENDAHULUAN}

Kebersihan merupakan hal yang sangat penting dan harus diperhatikan karena kebersihan akan mempengaruhi kesehatan, kenyamanan, keamanan, dan kesejahteraan. Praktik hygiene seseorang dipengaruhi oleh faktor pribadi, sosial dan budaya. Jika seseorang sakit, biasanya masalah kebersihan kurang diperhatikan terutama pada lansia. Hal ini terjadi karena biasanya menganggap masalah kebersihan adalah masalah sepele, padahal jika hal tersebut dibiarkan terus dapat mempengaruhi kesehatan (Marwah, 2014).

Dukungan keluarga merupakan suatu proses hubungan antar keluarga yang diperlihatkan melaluisikap, tindakan dan penerimaan keluarga yang terjadi selama masa hidup. Dukungan keluarga dapat berupa dukungan internal yang dapat diterima dari suami, isteri, atau dukungan dari saudara kandung dan dapat juga berupa dukungan eksternal dari keluarga inti. Dukungan yang diberikan keluarga berupa dukungan instrumental,

dukungan informasional, dukungan penilaian dan dukungan emosional. Rendahnya dukungan keluarga berhubungan dengan peningkatan angka kesakitan dan kematian (Permatasari, 2014).

Umur manusia sebagai makhluk hidup akan berkurang oleh suatu peraturan alam dan semua orang akan mengalami proses menjadi tua dan merasa tua merupakan masa hidup manusia yang terakhir yang pada masa ini seseorang mengalami kemunduran fisik/biologis, mental dan sosial sedikit demi sedikit. Penurunan fisik pada seseorang akan mempengaruhi kemandirian yang berdampak pada perilaku personal hygiene (Maryati, 2014).

Lanjut usia adalah periode dimana organisme telah mencapai kematangan dalam ukuran, fungsi dan telah menunjukkan perubahan sejalan dengan waktu. Beberapa pendapat mengenai usia yaitu usia tahap akhir dari proses penuaan menetapkan 60 tahun, 65 tahun dan 70 tahun (Handayani, 2014).

World Health Organization (WHO) tahun 2015 melaporkan populasi lansia di dunia mencapai 
900 juta dengan usia rata-rata 60 tahun dan tahun 2050 akan mencapai 2 milyar. Sedangkan jumlah lansia di Indonesia pada tahun 2015 sebanyak 19.142.805 jiwa $(7,59 \%)$ dari total 252.124.458 jiwa (Kemenkes RI, 2015). Sedangkan data dari BPS Provinsi Papua tahun 2015, jumlah penduduk lansia sebanyak 35.934 $(1,03 \%)$ dari total jumlah penduduk 3.486.432 jiwa. Jumlah lansia di Kabupaten Jayapura sebanyak 1.073 $(0,90)$ jiwa dari total jumlah penduduk 118.789 jiwa.

Lanjut usia banyak mengalami kemunduran fisik, psikis dan sosial yang dapat digambarkan melalui tiga tahap, yaitu kelemahan, keterbatasan fungsional, ketidakmampuan dan keterhambatan yang akan dialami bersamaan dengan proses kemunduran akibat proses menua (Chuluk, 2013). Kehidupan lansia yang sudah banyak mendapatkan permasalahan baik masalah keterbatasan gerak fisik dapat mempengaruhi tindakan lansia dalam melakukan pemenuhan personal hygiene. Salah faktor yang mempengaruhi personal hygiene pada lansia adalah kondisi fisik, terutama yang mengalami penyakit tertentu atau kecacatan, sehingga memerlukan bantuan orang lain untuk melaksanakan perawatan kebersihan diri (Erdhayanti, 2013).

Keluarga merupakan support system utama bagi lansia dalam mempertahankan kesehatannya. Peranan keluarga antara lain menjaga atau merawat lansia, mempertahankan dan meningkatkan status mental, mengantisipasi perubahan status sosial ekonomi serta memberikan motivasi dan memfasilitasi kebutuhan spiritual bagi lansia. Untuk meningkatkan pelayanan perawatan lansia oleh keluarga dibutuhkan dukungan diantaranya motivasi dan dukungan keluarga. Keluarga adalah unit terkecil dari masyarakat yang terdiri atas kepala keluarga dan beberapa orang yang berkumpul dan tinggal disuatu atap dalam keadaan saling ketergantungan (Harmoko, 2012). Dukungan keluarga merupakan dukungan sosial berupadukungan instrumental, informasional, penilaian dan emosional (Prasetyawati, 2012). 
Hasil penelitian Erdhayanti (2013), mengungkapkan bahwa dukungan keluarga berpengaruh terhadap pemenuhan personal hygiene. Pemenuhan personal hygiene yang kurang pada responden lansia banyak dijumpai pada waktu observasi di sore hari. Lansia banyak yang dalam satu hari hanya mandi satu kali. Pada sore hari, responden hanya melakukan cuci muka, tanpa menggunakan sabun pembersih, namun dengan adanya dukungan keluarga yang baik membantu lansia dalam pemenuhan personal hygiene.

Berdasarkan pengambilan data awal pada hari Senin Tanggal 2 Mei 2016, didapat data bahwa terdapat 62 orang lansia di Panti Bina Lanjut Usia Kabupaten Jayapura. Beberapa diantara lansia tersebut tampak rapi, tampak kotor dan tampak tidak terawat. Demikian juga aktivitas lansia ada yang tampak rajin dan tampak bersemangat tetapi ada juga yang tampak lesu dan malas. Berdasarkan wawancara singkat dengan beberapa lansia, ada beberapa keluarga dari lansia yang masih menyempatkan diri untuk mengunjungi lansia di Panti, namun ada juga keluarga dari lansia yang tidak pernah mengunjungi lansia.

Berdasarkan permasalahan tersebut, maka penulis tertarik untuk melakukan penelitian tentang "Hubungan Dukungan Sosial Keluarga Terhadap Pelaksanaan Personal Hygiene Lansia di Panti Bina Lanjut Usia Kabupaten Jayapura”.

\section{METODE PENELITIAN}

Penelitian ini merupakan penelitian deskriptif analitik dengan rancangan penelitian cross sectional study, yakni variabel dukungan sosial keluarga terhadap pelaksanaan personal hygiene pada lansia diukur secara bersamaan dalam satu waktu untuk mengetahui hubungan antara variabel tersebut (Notoatmodjo, 2012).

Penelitian ini dilakukan di Panti Bina Lanjut Usia Jayapura pada tanggal 30 Juni sampai dengan 1 Juli 2016.

Populasi dalam penelitian ini adalah seluruh populasi di Panti Bina Lanjut Usia Kabupaten Jayapura berjumlah 43 orang. Besar sampel menggunakan total sampling, 
sehingga jumlah sampel sebanyak 43 lansia.

Instrumen penelitian ini menggunakan kuesioner dukungan sosial keluarga dan personal hygiene. Analisa bivariat dilakukan untuk mengetahui hubungandukungan sosial keluarga terhadap pelaksanaan personal hygiene lansia. Selanjutnya data yang telah terkumpul diolah dengan menggunakan uji statistik $c h i$ square responden dengan tingkat signifikansi $\alpha \leq 0,05$. Dengan kesimpulan apabila $\rho \leq 0,05$ : Ho ditolak, yang menunjukkan adanya hubungan. Bila $\rho>0,05$ : Ho diterima, yang menunjukkan tidak adanya hubungan.

\section{HASIL DAN PEMBAHASAN}

\section{Karakteristik Lansia}

Berdasarkan data lansia menurut distribusi umur, hasil penelitian menunjukkan bahwa lansia di Panti Bina Lanjut Usia Kabupaten Jayapura sebagian besar berumur antara 60-74 tahun sebanyak 32 lansia $(74,4 \%)$ dan umur $\geq 75$ tahun sebanyak 11 lansia $(25,6 \%)$.
Distribusi lansia menurut jenis kelamin menunjukkan bahwa lansia di Panti Bina Lanjut Usia Kabupaten Jayapura terbanyak yaitu lansia perempuan sebanyak 29 orang (67,4\%), sedangkan lansia laki-laki sebanyak 14 lansia (32,6\%).

Berdasarkan tingkat pendidikannya, hasil penelitian menunjukkan bahwa lansia di Panti Bina Lanjut Usia Kabupaten Jayapura sebagian besar memiliki tingkat pendidikan SD sebanyak 29 lansia $(67,4 \%)$, selanjutnya Tidak Sekolah sebanyak 8 lansia $(18,6 \%)$, SMP sebanyak 4 lansia $(9,3 \%)$ dan terendah dengan tingkat pendidikan SMA sebanyak 2 lansia $(4,7 \%)$.

Menurut pekerjaannya, data menunjukkan bahwa lansia di Panti Bina Lanjut Usia Kabupaten Jayapura secara keseluruhan tidak bekerja.

\section{Analisa Univariat \\ Dukungan Sosial Keluarga}

Data dukungan sosial keluarga diperoleh setelah responden mengisi kuesioner tentang dukungan sosial keluarga. Skor jawaban responden kemudian dikategorikan sesuai dengan definisi operasional, yaitu 
dukungan sosial keluarga kurang jika skor jawaban $<62,5 \%$ dan dukungan sosial keluarga baik jika skor jawaban $\geq 62,5 \%$.

Hasil penelitian menunjukkan bahwa dukungan sosial keluarga dalam memenuhi kebutuhan personal hygiene lansia pada dukungan instrumental diperoleh kategori kurang sebanyak 13 orang $(30,2 \%)$ dan dukungan baik sebanyak 30 orang $(69,8 \%)$. Dukungan informasional diperoleh kategori kurang sebanyak 30 orang $(69,8 \%)$ dan dukungan baik sebanyak 13 orang $(30,2 \%)$. Dukungan penilaian kategori kurang sebanyak 23 orang $(53,5 \%)$ dan kategori baik sebanyak 20 orang (46,5\%). Sedangkan dukungan emosional kategori kurang sebanyak 27 orang $(62,8 \%)$ dan kategori baik sebanyak 16 orang $(37,2 \%)$. Dukungan sosial keluarga lansia di Panti Bina Lanjut Usia Kabupaten Jayapura sebagian besar dukungan sosial keluarga kurang sebanyak 23 orang $(53,5 \%)$ dan terendah dukungan sosial keluarga baik sebanyak 20 orang $(46,5 \%)$.
Keluarga adalah anggota rumah tangga yang saling berhubungan melalui pertalian darah adaptasi atau perkawinan. Keluarga adalah sekelompok manusia yang tinggal dalam suatu rumah tangga dalam kedekatan yang konsisten dan hubungan yang erat (Andriani, 2015). Dalam sebuah keluarga dibutuhkan adanya sebuah dukungan sesama antara keluarga. Dukungan sosial keluarga adalah suatu proses hubungan antara keluarga dan lingkungan sosialnya. Dukungan sosial keluarga juga merupakan sikap, tindakan dan penerimaan keluarga terhadap anggotanya. Anggota keluarga memandang bahwa orang yang bersifat mendukung selalu siap memberikan pertolongan dan bantuan jika diperlukan (Nango, 2015).

Kualitas hidup lansia dipengaruhi oleh beberapa faktor, salah satunya adalah dukungan keluarga.Dukungan keluarga adalah suatu bentuk perilaku melayani yang dilakukan oleh keluarga baik dalam bentuk dukungan instrumental, informasional, penilaian dan emosional (Friedman, 2010 dalam 
Yenni 2011). Dukungan keluarga termasuk dalam faktor pendukung yang dapat mempengaruhi perilaku dan gaya hidup seseorang sehingga berdampak pada status kesehatan dan kualitas hidupnya.

Pelaksanaan Personal Hygiene Lansia

Data pelaksanaan personal hygiene lansia diperoleh setelah responden mengisi kuesioner tentang personal hygiene. Skor jawaban responden kemudian dikategorikan sesuai dengan definisi operasional, yaitu pelaksanaan personal hygiene kurang jika skor jawaban < 62,5\% dan pelaksanaan personal hygiene baik jika skor jawaban $\geq 62,5 \%$.

Pada pelaksanaan personal hygiene di Panti Bina Lanjut Usia sebagian besar dilakukan dengan baik sebanyak 30 orang $(69,8 \%)$ dan sedikit yang melaksanakan personal hygiene kurang sebanyak 13 orang $(30,2 \%)$. Hal ini menunjukkan kesadaran lansia yang baik dalam pemenuhan personal hygiene lansia.

Personal hygiene adalah cara perawatan diri manusia untuk memelihara kesehatan mereka secara fisik dan keadaan emosional.
Pemeliharaan personal hygiene diperlukan untuk kenyamanan individu, keamanan dan kesehatan (Sulistyowati, 2015).

Menurut Riyadi \& Widuri (2015) dampak rendahnya pemenuhan personal hygiene lansia berakibat banyak terjadinya gangguan kesehatan yang diderita seseorang karena tidak terpelihara kebersihan perorangan dengan baik. Gangguan fisik yang sering terjadi adalah gangguan integritas kulit, gangguan membran mukosa mulut, infeksi pada mata dan telinga dan gangguan fisik pada kuku.Sedangkan dampak psikososial berhubungan dengan gangguan kebutuhan rasa nyaman, kebutuhan dicintai dan mencintai, kebutuhan harga diri, aktualisasi diri dan gangguan interaksi sosial.

Lansia sangat berisiko terhadap berbagai penyakit, dengan pemenuhan personal hygiene yang baik maka lansia dapat terhindar dari risiko timbulnya penyakit.

\section{Analisa Bivariat}

Pegujian hipotesis mengenai hubungan dukungan sosial keluarga terhadap pelaksanaan personal 
hygiene lansia di Panti Bina Lanjut Usia Kabupaten Jayapura menggunakan uji statistik chi square.

Hasil penelitian menunjukkan bahwa pelaksanaan personal hygiene kurang yang dilakukan lansia sebanyak 7 orang $(47,8 \%)$ dengan dukungan sosial keluarga kurang, sedangkan pelaksanaan personal hygiene baik yang dilakukan lansia sebanyak 6 orang (10\%) dengan dukungan sosial keluarga baik. Hasil uji statistik chi square pada nilai kemaknaan $95 \%(\alpha=0,05)$ diperoleh p-value 0,018 atau $\mathrm{p}<\alpha(0,05)$, hal ini menunjukkan ada hubungan dukungan sosial keluarga terhadap pelaksanaan personal hygiene lansia di Panti Bina Lanjut Usia Kabupaten Jayapura. Bila dilihat dari nilai $\mathrm{RP}=$ 2,724 menunjukkan bahwa lansia yang kurang mendapat dukungan keluarga memiliki peluang kurang dalam pelaksanaan personal hygiene 4,78 kali lebih besar dibandingkan lansia yang mendapat dukungan keluarga yang baik.

Penelitian ini diperoleh data bahwa lansia yangmendapat dukungan keluarga baik dan pelaksanaan personal hygiene baik disebabkan keluarga memenuhi kebutuhan personal hygiene lansia dan adanya kesadaran dari lansia dalam perawatan dirinya sendiri. Selain itu lansia juga mendapat dukungan dari pengelola panti sebagai pengganti keluarga dalam pemenuhan personal hygiene.

Hal ini sesuai dengan teori Katz dalam Alasmyah (2014) pada teori perilaku terencana bahwa seseorang dapat melaksanakan sebuah perilaku berdasarkan dari adanya kontrol internal dan eksternal. Internal control factors adalah faktor-faktor yang meliputi kemampuan, keterampilan dan adanya informasi yang didapat oleh seseorang akan memudahkan mereka dalam berperilaku.

Adanya bantuan dan dukungan dari keluarga, teman-teman dan pengelola panti, maka sebagian besar masalah personal hygiene lansia dapat terpenuhi sehingga risiko timbulnya penyakit dapat dicegah.

Lansia perlu mendapatkan perhatian serta dukungan yang baik dari keluarga dan lingkungan terdekat. Dukungan dari keluarga merupakan unsur terpenting dalam 
pemenuhan kebutuhan perawatan diri. Apabila terdapat dukungan, rasa percaya diri akan bertambah dan motivasi untuk mengatasi masalah yang terjadi akan meningkat sehingga dalam menjalani kehidupan sebagai lansia berjalan dengan optimal. Hal ini diperkuat dari nilai rasio prevalensi bahwa lansia yang kurang mendapat dukungan keluarga memiliki peluang kurang dalam pelaksanaan personal hygiene 4,78 kali lebih besar dibandingkan lansia yang mendapat dukungan keluarga yang baik.

\section{KESIMPULAN}

1. Dukungan sosial keluarga lansia dalam pemenuhan personal hygiene lansia di Panti Bina Lanjut Usia Kabupaten Jayapura sebagian besar kurang $(53,5 \%)$.

2. Pelaksanaan personal hygiene lansia di Panti Bina Lanjut Usia Kabupaten Jayapurasebagian besar dilakukan dengan baik $(69,8 \%)$.

3. Ada hubungan dukungan sosial keluarga terhadap pelaksanaan personal hygienelansia di Panti
Bina Lanjut Usia Kabupaten Jayapura.

\section{SARAN}

1. Bagi Keluarga

Sangat penting bagi keluarga dalam memberikan dukungan dan motivasi kepada lansia dalam pemenuhan personal hygiene.

2. Bagi Lansia

Agar lebih menjaga personal hygiene mengingat personal hygiene sangat penting bagi lansia karena sangat rentan terhadap penyakit.

3. Bagi Panti Bina Lanjut Usia

Agar lebih memperhatikan persediaan perlengkapan alat mandi seperti shampo dan alat gunting kuku guna mencegah timbulnya penyakit yang diakibatkan karena kurangnya personal hygiene.

4. Bagi peneliti selanjutnya

Bagi peneliti selanjutnya dapat meneliti hubungan status kesehatan, tingkat depresi dengan pemenuhan personal hygiene pada lansia. 


\section{DAFTAR PUSTAKA}

Alamsyah, D. (2014). Pilar Dasar Ilmu Kesehatan Masyarakat. Yogyakarta: Nuha Medika.

Andriani, S. (2015). Hubungan Dukungan Keluarga Dengan Depresi Pada Lansia Di Balai Perlindungan Sosial Tresna Werdha Ciparay Bandung. Jurnal Keperawatan Aisyah. Volume 2 Nomor 1, Juni 2015. 27-36.

Badan Pusat Statistik Provinsi Papua (2015).

Chuluk. (2013). Hubungan Dukungan Keluarga Dengan Kemandirian Dalam Pemenuhan Activity Daily Living (ADL) Pada Lansia Wanita di Kampung Karang Werdha Puntodewo 1 Kelurahan Bunulrejo Malang. Universitas Brawijaya Malang. http://www.unbra.co.id. diakses 02 Mei 2016.

Data Profil Panti Bina Lanjut Usia Kabupaten Jayapura (2016).

Erdhayanti, S. (2013). Hubungan

Tingkat Pengetahuan Lansia Dengan Perilaku Lansia Dalam Pemenuhan Personal Hygiene di
Panti Sosial Tresna Werdha Darma Baktipajang Surakarta. http://www.umusurakarta.co.id. Diakses 02 Mei 2016.

Handayani, Z. M. (2014). Hubungan Peran Keluarga Dengan Pemenuhan Kebutuhan Perawatan Diri Pada Lanjut Usia di Dusun Jogonalan Lor Kasihan Bantul. http://www.stikesaisyah.co.id. Diakses 02 Mei 2016.

Harmoko. (2012). Asuhan Keperawatan Keluarga. Yogyakarta: Pustaka Pelajar.

Kemenkes RI (2015). Profil Kesehatan Indonesia. http://www.kemenkesri.go.id. Diakses 02 Mei 2016.

Maryati, H. (2014). Gambaran Fungsi Kognitif Pada Lansia Di UPT Panti Werdha Mojopahit Kabupaten Mojokerto. http://www.stikesjombang.co.id. Diakses 5 Mei 2016.

Marwah. (2014). Hubungan Dukungan Keluarga dengan Kemandirian Lansia dalam Pemenuhan Aktivitas Seharihari di Desa Sipodeceng 
Kecamatan Baranti Kabupaten

Sidrap. http//www.unhas.co.id.

Nango, M. I. (2015). Hubungan

Dukungan Keluarga dengan

Tingkat Depresi pada Lansia di

UPT Pelayanan Sosial Lansia

Pasuruan di Lamongan,

http://www.universitasgresik.co.

id. Diakses 02 Mei 2016.

Notoatmodjo. (2012). Metode

Penelitian Kesehatan. Jakarta:

Rineka Cipta.

Permatasari, L. I. (2014). Hubungan

Dukungan Keluarga dan Self

Efficacy dengan Perawatan Diri

Lansia

Hipertensi.

http://www.unpad.co.id. Diakses

02 Mei 2016

Prasetyawati. (2012). Ilmu

Kesehatan Masyarakat Untuk

Kebidanan Holistik. Nuha

Medika, Jakarta.

Riyadi, S., \& Widuri, H. (2015).

Kebutuhan Dasar Manusia

Aktitivitas Istirahat Diagnosis

Nanda. Yogyakarta: Goyen

Publishing.
Sugiyono. (2013). Metode Penelitian

Manajemen. Bandung: Alfabeta.

Sulistyowati, D. (2014). Peran

Perawat dalam Pelaksanaan

Personal Hygiene Menurut

Persepsi Pasien Imobilisasi

Fisik. e-journal Keperawatan (e-

Kp) Volume 3 Nomor 2, Mei

2015.

WHO. (2015). World Population Ageing. http://www.who.com. diakses 21 Mei 2016. 